\title{
Reduction of serotonergic gene expression in the raphe nuclei of the midbrain under positive fighting experience in male mice
}

\author{
Dmitry A. Smagin ${ }^{1 *}$, Ul’yana A. Boyarskikh ${ }^{2 *}$, Natalya P. Bondar ${ }^{1}$, Maxim L. Filipenko², \\ Natalia N. Kudryavtseva ${ }^{1 \#}$ \\ ${ }^{1}$ Institute of Cytology and Genetics, Siberian Department of Russian Academy of Sciences, Novosibirsk, Russia \\ ${ }^{2}$ Institute of Chemical Biology and Basic Medicine, Siberian Department of Russian Academy of Sciences, Novosibirsk, Russia \\ Email: "n.n.kudryavtseva@gmail.com, natnik@bionet.nsc.ru
}

Received 15 July 2013; revised 15 August 2013; accepted 20 September 2013

Copyright (C) 2013 Dmitry A. Smagin et al. This is an open access article distributed under the Creative Commons Attribution License, which permits unrestricted use, distribution, and reproduction in any medium, provided the original work is properly cited.

\begin{abstract}
The concept of a major inhibitory role of serotonin in aggressive behavior is widely accepted by investigators. There was ample evidence that a pharmacologically-induced increase in the serotonin activity attenuates agonistic behavior in animals, and that the manipulations inhibiting the brain serotonergic system can elicit aggressiveness in male mice and rats. Repeated experience of aggression in daily agonistic interactions has been shown to reduce serotonin activity in brain of victorious male mice. The study aimed to analyze expression of the serotonergic genes -Tph2, Sert, Maoa and Htr1a, as well as the Bdnf and Creb genes in the midbrain raphe nuclei of male mice with positive fighting experience in daily encounters and male mice with the same track record of aggression followed by two-week no-fight period. It has been shown that mRNA levels of the serotonergic and Creb genes are reduced in the winners in comparison with male mice without consecutive positive fighting experience of aggression. After the fighting deprivation the Tph2, Sert, Bdnf and Creb genes recover their expression while mRNA levels of the Maoa and Htr1a genes proceed at a significantly higher level as compared with the respective controls. Downregulation of serotonergic genes is indicative of the inhibition of serotonergic activity under repeated experience of aggression. Nevertheless recovering of $T p h 2$ and Sert gene expression and overexpression of the Maoa and Htr1a genes after no-fight period suggest that changes in brain serotonergic activity are not main cause of
\end{abstract}

\footnotetext{
*These authors contributed equally to this work

${ }^{\#}$ Corresponding author.
}

the behavioral pathology developing in male mice in this experimental context.

Keywords: Tph2; Sert; MaoA; Bdnf; Creb; mRNA; Repeated Aggression; Fighting Deprivation

\section{INTRODUCTION}

The concept of a major inhibitory role of serotonin (5HT) in aggressive behavior is widely accepted by investigators. There was ample evidence that a pharmacologically-induced increase in 5-HT activity attenuates agonistic behavior in animals and that the manipulations inhibiting the brain serotonrgic system can elicit aggressiveness in male mice and rats [1-7]. It has been shown that after fights 5-HT level decreases in the prefrontal cortex in aggressive rats [8]. Reduced cerebrospinal fluid (CSF) level of the 5-HT major metabolite 5-hydroxyindoleacetic acid (5-HIAA), as well as decreased sensitivity of $5-\mathrm{HT}_{1 \mathrm{~A}}$ receptors shown in prisoners or psychiatric patients with repeated violent or aggressive acts [913 ], also suggests a reduced overall 5-HT function in aggressive individuals.

Experimental studies in male mice with repeated experience of aggression accompanied by social victories in daily agonistic interactions have demonstrated reduced 5-HIAA level or/and 5-HIAA/5-HT ratio $[14,15]$ and a decrease in the activity of rate-limiting enzyme in the 5HT biosynthesis, tryptophan hydroxylase, in brain areas such as the midbrain, hippocampus and striatum $[16,17]$. Specific changes in pharmacological sensitivity of 5$\mathrm{HT}_{1 \mathrm{~A}}$ receptors to agonist of $5-\mathrm{HT}_{1 \mathrm{~A}}$ receptor buspirone [18] and in $5-\mathrm{HT}_{1 \mathrm{~A}}$ receptor binding in the frontal cortex, hippocampus and hypothalamus have been demonstrated in male mice with repeated aggression [19]. All these fin- 
dings are consistent with the 5-HT deficiency hypothesis of aggression [15].

The study aimed to elicit a possible role of the serotonergic Tph2, Sert, MaoA, 5-HT1a genes, encoding the tryptophan hydroxylase, 5-HT transporter, monoamine oxidase $\mathrm{A}$ and $5-\mathrm{HT}_{1 \mathrm{~A}}$ receptors, respectively, which may be involved into regulations of positive fighting experience. Expression of the Bdnf (encoding brain-derived neutrophic factor) and $\mathrm{Creb}$ (encoding cyclic AMP response element binding protein) genes was also studied. The focus was on the area of the midbrain raphe nuclei containing the cell bodies of serotonergic neurons. The mRNA levels were analyzed in male mice that had a long positive fighting history (21 wins in daily agonistic interactions). Since the behavioral data indicated that the implications of chronic aggression persist at least two weeks after the cessation of agonistic interactions $[15,20$, 21 , the expression of serotonergic genes was also analyzed in a group of 21-time winners who were kept away from agonistic interactions referred to as "no-fight period" or "fighting deprivation" throughout. Such animals are special as they appear to be more aggressive after nofight period than before. The comparison of the expression of genes in these groups of the winners helps answer the question on whether or not the altered gene expression in the midbrain raphe nuclei of the fighting deprived winners recovers after no-fight period to the control levels.

\section{MATERIALS AND METHODS}

\subsection{Animals}

Adult male mice of the C57BL/6J strain from a stock maintained in the Animal Facility of the Institute of Cytology and Genetics, SD RAS, (Novosibirsk, Russia) were used. The animals were housed under standard conditions [12:12-h light/dark regime, switch on at 8.00 a.m.; food (pellets) and water available ad libitum]. Mice were weaned at one month of age and housed in groups of eight to ten in plastic cages $(36 \times 23 \times 12 \mathrm{~cm})$. Experiments were performed on mice $10-12$ weeks of age.

All procedures were in compliance with the European Communities Council Directive of November 24, 1986 (86/609/EEC). The study protocol was approved by the Scientific Committee N 9 on the Ethics of Animal Experiments in the Institute of Cytology and Genetics SD RAS (Permit Number: N 613).

\subsection{Sensory Contact Model for the Study of Agonistic Behavior in Male Mice}

Repeated experience of aggression accompanied by social victories in male mice was induced using the sensory contact model [22-24]. Pairs of weight-matched animals were each placed in a steel cage bisected by a perforated transparent partition allowing the animals to see, hear and smell each other, but preventing physical contact. The animals were left undisturbed for three days to adapt to new housing conditions and sensory contact before they were exposed to encounters. Every afternoon (1400 - 1700 hours, local time), the cage lid was replaced by a transparent one, and $5 \mathrm{~min}$ later (the period necessary for individuals' activation), the partition was removed for 10 minutes to encourage agonistic interactions. The superiority of one of the mice was firmly established within two or three encounters with the same opponent. The superior mouse (winners) would be attacking, biting and chasing another, who would be displaying only defensive behavior (sideways postures, upright postures, withdrawal, lying on the back or freezing). As a rule, agonistic interactions between males are discontinued by lowering the partition if the strong aggression has lasted $3 \mathrm{~min}$, in some cases, less. Each defeated mouse (defeater, loser) was exposed to the same winner for three days, while afterwards each loser was placed, once a day after the fight, in an unfamiliar cage with an unfamiliar winner behind the partition. Each victorious mouse remained in its original cage. This procedure was performed once a day for 21 days and yielded an equal number of the winners and losers.

Three groups of animals were used: (1) Winners-a group of mice with repeated experience of aggression accompanied by victories during 21 days of agonistic interactions; (2) Fighting deprived winners-a group of chronically victorious 21 -time mice who lived for 14 days after the last encounter without agonistic interactions (period of fighting deprivation). During this period, each of them shared a cage with a losers, the partition between their compartments being down at all times, to prevent physical encounters; (3) Controls - the mice without consecutive experience of agonistic interactions. To the end of experiment, animals of all experimental groups were 15 17 weeks of age.

To measure mRNA levels in the raphe nuclei area of midbrain, all the mice were decapitated simultaneously: 21-time winners, 24 hours after the last agonistic interaction; fighting deprived winners, immediately after 14-day period of deprivation; and the controls. The raphe nuclei areas were dissected in animals according to the Mouse Brain Atlas [25]. The mouse brains were removed and chilled rapidly on ice. Dissection of the brain regions was made by one experimenter during two consecutive days. Animals of all groups were represented in each day. All biological samples were encrypted, rapidly frozen in liquid nitrogen, and stored at $-70^{\circ} \mathrm{C}$ until use.

\subsection{Behavioral Study}

Behavior of each winner in agonistic interaction test was videorecorded for 10 min during its last encounter, and 
the data were documented. Furthermore, we needed to know whether both groups of the winners could be considered identical at the time each mouse was won its last encounter. To find out, the groups were compared in terms of behavior. During a 10-min test, the following were the behavioral domains analyzed in the winners: (1) Attacks: attacking, biting and chasing; (2) Aggressive grooming - the winner mounts onto the loser's back, holds it down and spends much time licking and nibbling at the loser's scruff of the neck. The loser is wholly immobilized or sometimes stretches out the neck and again freezes under the winner; (3) Digging - digging up and scattering the sawdust on the loser's territory (kick-digs: pulling the sawdust forwards with the forepaws; pushdigs: pushing the sawdust backwards with the hind paws); (4) Hostile behavior - the total time spent attacking, aggressively grooming and digging; (5) Self-grooming-body care activities (fur licking, head washing, nose washing). The total time and/or number of behavioral events were measured.

\subsection{Total RNA Extraction and Reverse Transcription}

Total RNA was isolated from the tissues using TRIzol (Invitrogen) according to the manufacturer's instructions. The concentration of total RNA was quantified by measuring the absorbance at $260 \mathrm{~nm}$. The integrity of total RNA was assessed using agarose gel electrophoresis. cDNAs were synthesized using total RNA $(1 \mu \mathrm{g})$, random N9 primer (100 ng), and MoMLV reverse transcripttase (200 U, Biosan). Each RT reaction was run in duplicate. RNA aliquots were used to confirm the absence of any genomic DNA in each sample.

\subsection{Real-Time Quantitative PCR}

The Tph2, Sert, Maoa, Htr1a, Bdnf, Creb, Cphn, Gapdh, and Hprt cDNA levels were quantified by SybrGreenbased real-time PCR in a total volume of $25 \mu$ containing an aliquot of the RT mixture, dNTPs $(200 \mathrm{nM}), \mathrm{F}$ and $\mathrm{R}$ primers (300 $\mathrm{nM})$, SybrGreen I (1:20,000, Invitrogen), standard PCR buffer, and hot-start TaqDNA polymerase (0.5 U, Biosan). Amplification was run for $3 \mathrm{~min}$ at $95^{\circ} \mathrm{C}$ followed by 40 cycles of $6 \mathrm{~s}$ at $96^{\circ} \mathrm{C}, 6 \mathrm{~s}$ at $60^{\circ} \mathrm{C}, 12 \mathrm{~s}$ at $72^{\circ} \mathrm{C}$. Fluorescence was monitored for $5 \mathrm{~s}$ after each cycle at the appropriate melting temperature. To check for the presence of nonspecific PCR products or primer dimers, a melting curve analysis was performed after the final PCR cycle. Cphn, Gapdh, and Hprt were considered initially as possible housekeeping (normalizers) genes in this study.

Amplification efficiencies were calculated using a relative standard curve derived from threefold serial dilutions of pooled cDNA. In all cases, the amplification efficiency was higher than $90 \%$. Each sample was PCRamplified twice. qRT-PCR results were quantified using the relative standard curve method. The PCR primer sequences are shown in Table 1. Samples from animals of different experimental groups were mixed before molecular study. Extraction of total RNA, reverse transcription, and qRT-PCR were made during 2 weeks by one experimenter in blind regimen with use of one buffer and primers set.

\subsection{Statistical Analysis}

Normal distribution and homogeneity of variances were tested by the Shapiro-Wilk's and Levene's tests, respectively. Statistical analysis of behavioral data was performed pairwise comparison of the groups with t-Student test or the Mann-Whitney $U$ test. Statistical analysis of mRNA levels was performed using one-way ANOVA with factor "groups" under the consideration - the controls, winners, and fighting deprived winners - followed by the comparison of the groups using the Bonferroni post hoc testing or Fisher LSD test. The data are reported as mean $\pm \mathrm{SEM}$. The statistical significance was set at $\mathrm{P}$ $\leq 0.05$.

For each experimental sample, the relative amount of mRNA is determined from the appropriate standard curve. Since the all reference genes, Cphn, Gapdh, and Hprt, changed their expression under repeated experience of aggression in the midbrain raphe nuclei in the winners as compared with the controls, we can't use them to obtain a normalized level of the Bdnf, Creb, Tph2, Sert, Maoa, and Htrla genes. The other statistical approach [26] was used to reveal differences in serotonergic and other genes expression between the experimental groups: the mean of relative amount of mRNA in the control group for each gene was taken as $100 \%$, and changes in the winners, fighting deprived winners, and controls were calculated as percentage of the mean in the controls. In the control group, the number of animals used in experiment was 16 - 17. Groups of 21-time winners and fighting deprived winners contained $11-13$ mice.

\section{RESULTS}

\subsection{Analysis of the Winners' Behavior in Agonistic Interactions}

We needed at first to know whether both groups of the aggressive mice (winners) could be considered identicallat the time each mouse was won its last encounter. If they were, all the differences in genes' expression between group of 21-time winners and group of 21-time winners before fighting deprivation, or lack thereof, could solely be accounted for by deprivation. To find out, the animals were compared in terms of aggressive be 
Table 1. Primer sequences.

\begin{tabular}{|c|c|c|c|}
\hline Genes & & Primer sequences & Functions \\
\hline \multirow[t]{2}{*}{ Bdnf } & $\mathrm{F}$ & 5'-CAAACAAGACACATTACCTTCCT-3' & Brain-derived neurotrophic factor \\
\hline & $\mathrm{R}$ & 5'-ATGGTCATCACTCTTCTCACCT-3' & \\
\hline \multirow[t]{2}{*}{ Creb } & $\mathrm{F}$ & 5'-CAGCCACAGATTGCCACATTAG-3' & Cyclic AMP response element binding protein \\
\hline & $\mathrm{R}$ & 5'-CTTATGGAGACTGGATAACTGATG-3' & \\
\hline \multirow{2}{*}{ Tph2 } & $\mathrm{F}$ & 5'-CACCATTGTGACCCTGAATCC-3' & Tryptophan hydroxylase 2-rate-limiting enzyme of 5-HT synthesis \\
\hline & $\mathrm{R}$ & 5'-AAGCTCGGTGCCGTACATGAG-3' & \\
\hline \multirow[t]{2}{*}{ Sert } & $\mathrm{F}$ & 5'-GCTGAGATGAGGAACGAAGAC-3' & Serotonin transporter protein \\
\hline & $\mathrm{R}$ & 5'-AGGAAGAAGATGATGGCAAAG-3' & \\
\hline \multirow[t]{2}{*}{ Maoa } & $\mathrm{F}$ & 5'-GAATGTCAATGAGCGTCTAGTTC-3' & Monoamine oxidase A, enzyme of 5-HT catabolism \\
\hline & $\mathrm{R}$ & 5'-ATGGTGCATCAACAGGGATCTC-3' & \\
\hline \multirow[t]{2}{*}{$5 h t 1 a$} & $\mathrm{~F}$ & 5'-TTGGAACTACTTTGGGTTATGG-3' & Serotonin $5-\mathrm{HT}_{1 \mathrm{~A}}$ receptors \\
\hline & $\mathrm{R}$ & 5'-ATTGTCAATTTCTTTGGTGAGTG-3' & \\
\hline \multirow[t]{2}{*}{ Cphn } & $\mathrm{F}$ & 5'-GTTTTTTATCTGCACTGCCAAG-3' & $\begin{array}{l}\text { PPIA - peptidylprolyl isomerase A (cyclophilin A); } \\
\text { enzyme accelerates folding of proteins }\end{array}$ \\
\hline & $\mathrm{R}$ & 5'-TTCTTGCTGGTCTTGCCATTC-3' & \\
\hline \multirow[t]{2}{*}{ Gapdh } & $\mathrm{F}$ & 5'-TGTTCCAGTATGACTCCACTCA-3' & Glyceraldehyde-3-phosphate dehydrogenase; glycolysis enzyme \\
\hline & $\mathrm{R}$ & 5'-GACACCAGTAGACTCCACGACA-3' & \\
\hline \multirow[t]{2}{*}{ Hprt } & $\mathrm{F}$ & 5'-TGAAAAGGACCTCTCGAAGTGT-3' & $\begin{array}{l}\text { Hypoxanthine-guanine phosphoribosyltransferase; synthesis of purine } \\
\text { nucleotides through the purine salvage pathway }\end{array}$ \\
\hline & $\mathrm{R}$ & 5'-CACTAATGACACAAACGTGATTC-3' & \\
\hline
\end{tabular}

grooming, digging etc. No differences were found between these groups of the winners in any of the individual or social behaviors measured after the respective 21day periods of agonistic interactions $(P>0.05$, Table 2$)$.

\subsection{Cphn, Gapdh, and Hprt Genes}

Data obtained revealed a change in expression of the so-called housekeeping genes which we were going to use for normalization for the qRT PCR data: the expression of the Cphn, Gapdh, and Hprt genes used as putative reference genes decreased significantly in the midbrain raphe nuclei in the 21-time winners as compared with the controls. Similarly to previous study [26] as it turns out, the use of these genes as reference genes in the analysis of expression of other genes of interest was hardly possible. The method for calculating changes in the expression of each gene in the winners before and after deprivation versus its expression in the respective controls was used to reveal differences in all genes expression between the experimental groups [26].

One-way ANOVA revealed a significant influence of the factor groups (the control, winners and fighting deprived winners) on mRNA level of the Cphn $\left(F_{2,38}=\right.$ 9.58; $P<0.001)$, Gapdh $\left(F_{2,37}=4.77 ; P<0.014\right)$, and
$\operatorname{Hprt}\left(F_{2,39}=10.50 ; P<0.001\right)$ genes (Figure 1). Based on the post hoc Bonferroni test as compared to the respective levels in the controls, mRNA levels of the Cphn, Gapdh, and Hprt genes were decreased in the 21-time winners $(P<0.001, P<0.013, P<0.007$, respectively). In fighting deprived winners the Cphn mRNA level was significantly less $(P<0.035)$ and expression of the $G a-$ pdh and Hprt genes did not differ significantly in comparison with the controls. However expression of Hprt gene in the fighting deprived winners was significantly higher than in the winners before deprivation $(P<$ $0.001)$.

\subsection{Bdnf and Creb Genes}

One way ANOVA revealed a significant influence of the factor groups on the mRNA levels of the $\operatorname{Bdnf}\left(F_{2,39}=\right.$ 4.76; $P<0.014)$ and $\operatorname{Creb}\left(F_{2,38}=8.88 ; P<0.001\right)$ genes. Based on the Bonferroni post hoc test (Figure 2) as compared to the respective levels in the controls, mRNA levels of the Creb gene were decreased $(P<0.008)$ in the 21-time winners. In the fighting deprived winners, the $B d n f$ and Creb mRNA level was higher than in the winners before deprivation $(P<0.012$ and $P<0.001$, 
Table 2. Behavioral data from mice to become no-deprived winners and in mice to become post-deprived winners during their respective last encounter.

\begin{tabular}{|c|c|c|c|c|c|c|c|}
\hline Behavioral parameters & \multicolumn{3}{|c|}{ Mice to become no-deprived winners } & \multicolumn{3}{|c|}{ Mice to become post-deprived winners } & Unpaired t-test $\mathrm{M}-\mathrm{W}$ test \\
\hline \multicolumn{8}{|l|}{ Attacks } \\
\hline Latency, s & 54.7 & \pm & 15.7 & 55.4 & \pm & 17.8 & $\mathrm{t}=0.030 ; P<0.97$ \\
\hline Number & 11.2 & \pm & 1.9 & 9.0 & \pm & 1.7 & $\mathrm{t}=0.848 ; P<0.40$ \\
\hline Total time, s & 50.5 & \pm & 12.1 & 43.7 & \pm & 7.8 & $\mathrm{t}=0.848 ; P<0.64$ \\
\hline Aggressive grooming, $\mathrm{s}$ & 27.4 & \pm & 17.2 & 23.4 & \pm & 16.9 & $\mathrm{U}=76 ; P<0.98$ \\
\hline Diggings, s & 18.1 & \pm & 3.5 & 18.6 & \pm & 2.4 & $\mathrm{t}=0.126 ; P=0.90$ \\
\hline Hostile behavior, s & 95.9 & \pm & 18.8 & 85.7 & \pm & 17.8 & $\mathrm{t}=0.386 ; P<0.70$ \\
\hline Self-grooming, N & 19.2 & \pm & 3.7 & 14.9 & \pm & 3.6 & $\mathrm{t}=0.817 ; P=0.42$ \\
\hline Number of animals & & 14 & & & 11 & & \\
\hline
\end{tabular}

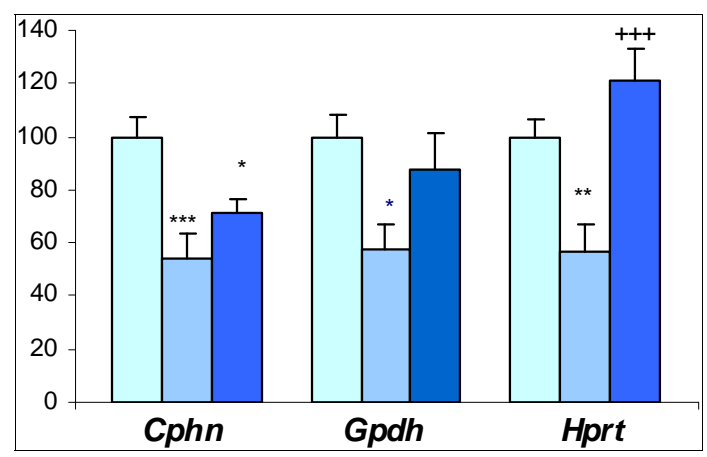

Figure 1. Cphn, Gapdh, and Hprt mRNA levels in the raphe nuclei of the midbrain in the controls (light blue columns), winners (blue columns), and fighting deprived winners (dark blue columns). Data are presented as percentage of the mean in the controls. ${ }^{*} P<$ $0.05 ;{ }^{* *} P<0.01 ;{ }^{* * *} P<0.001$ vs the controls; and ${ }^{++} P$ $<0.001$ vs the winners.

respectively).

\subsection{Tph2, Sert, Maoa, and Htr1a Genes}

One-way ANOVA revealed a significant influence of the factor groups on the mRNA level of the Tph2 $\left(F_{2,36}\right)=$ 5.36; $P<0.009)$, Sert $\left(F_{2,38}=4.79 ; P<0.014\right)$, Maoa, $\left(F_{2,39}=15.32 ; P<0.001\right)$ and Htrla $\left(F_{2,38}=37.84 ; P<\right.$ $0.001)$ genes. Based on the Bonferroni post hoc test (Figure 3) as compared to the respective controls, the mRNA levels of the Maoa and Htrla genes were decreased in the 21-time winners $(P<0.007$ and $P<$ 0.037 , respectively) and was increased in fighting deprived winners $(P<0.033$ and $P<0.001$, respectively). Significant differences were found between the winners before and after deprivation for the Tph2 $(P<0.007)$, Sert $(P<0.012)$, Maoa $(P<0.001)$, and Htrla $(P<$ $0.001)$ mRNA levels. Additionally, Fisher LSD test had demonstrated significant differences between the con-

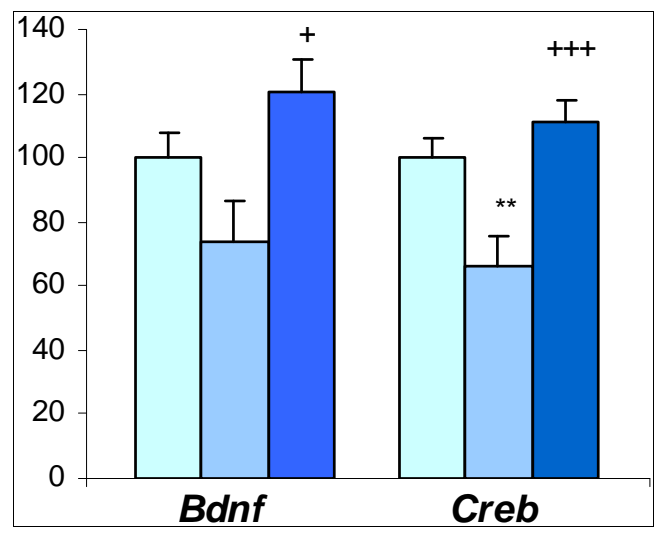

Figure 2. Bdnf and Creb mRNA levels in the raphe nuclei of the midbrain in the controls (light blue columns), winners (blue columns), and fighting deprived winners (dark blue columns). Data are presented as percentage of the mean in the controls. ${ }^{*} P$ $<0.05 ;{ }^{* *} P<0.01$; vs the controls; ${ }^{+} P<0.05 ;{ }^{+++} P$ $<0.001$; vs the winners.

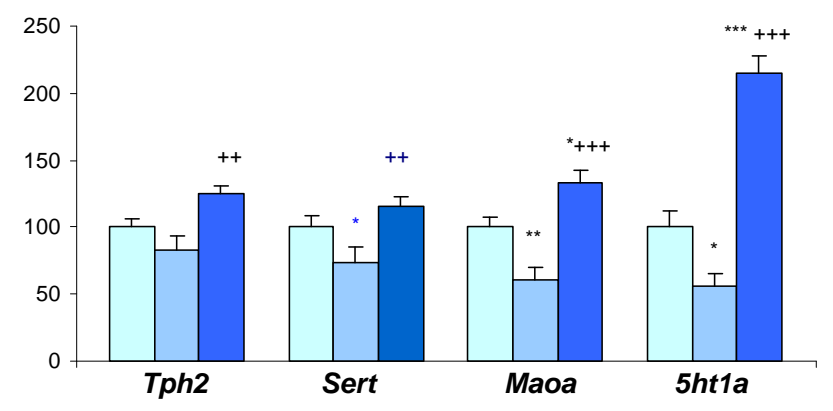

Figure 3. Tph2, Sert, Maoa, and Htrt1a mRNA levels in the raphe nuclei of the midbrain in the controls (light blue columns), winners (blue columns), and fighting deprived winners (dark blue columns). Data are presented as $\%$ of the mean in the controls. ${ }^{*} P<0.05 ;{ }^{* *} P<0.01$ and ${ }^{* * *} P<0.01$ vs the controls; ${ }^{+} P<0.05 ;{ }^{++} P<0.01 ;{ }^{+++} P<0.001$ vs the winners.

trols and winners for Sert mRNA levels $(P<0.043)$. 


\section{DISCUSSION}

Variability of the reference genes expression in different tissues and experimental situations was demonstrated in studies of last years [27-32]. We also found in the 21 time winners decrease in functional activity of the genes involved in the processes of intracellular protein transport (Cphn) and glycolysis (Gapdh), presented in all nucleated cells (Hprt), which suggests a profound influence of positive fighting experience on different metabolic and cellular processes in the raphe nuclei of the midbrain. It is noteworthy that 2 week no-fight period is enough for the Gapdh and Hprt genes but not for the Cphn gene to recover their expression to the control levels.

Transcription of the Bdnf gene is dependent on cAMP response element binding protein $(C R E B)$. In the midbrain raphe nuclei of the winners before and after fighting deprivation the expression of the Bdnf and Creb genes, encoding the proteins associated with neurotransmission, neurogenesis and synaptic plasticity [33], was shown to undergo changes similar to those in genes involved into the metabolic and cellular processes. Reduced Creb mRNA level was found in the raphe nuclei of the 21-time winners as compared with the controls. It is notable that the mRNA levels of both genes were significantly higher after a no-fight period than before it. Dynamic changes in the expression of these genes are likely to take place under experience of aggression and no-fight periods.

It has been shown many times that the Bdnf and Creb genes are involved in the brain mechanism of chronic social defeat stress [26,34-38]. At the same time, the experimental evidence of the role of these genes in the mechanisms of aggression is scarce and inconclusive. It has been shown that BDNF knockout mice exhibit elevated conspecific aggression and social dominance [39]. Schizophrenic patients with first-episode psychosis have lower serum concentrations of the BDNF and score higher on the Aggression-Hostility scale than healthy individuals [40]. Winning animals have significantly more Bdnf mRNA in the dentate gyrus of the dorsal hippocampus than losing animals and home cage controls [41]. Authors support a model in which BDNF-mediated plasticity within the hippocampus may instantiate aspects of winning such as control of a territory by dominant animals. The Bdnf mRNA level increases in ventral tegmental area of 21-time winners [42]. Obviously, further studies are needed to explore the role of the Bdnf and Creb genes in mechanisms of social aggression.

Research evidence shows that BDNF promotes the survival and differentiation of the 5-HT neurons [43]. It is reasonable to assume that changes in the functional activity of the Creb and Bdnf genes in the raphe nuclei containing the cell bodies of serotonergic neurons are attributable to changes in serotonergic activity of the brain shaped by repeated experience of aggression. The expe- riment demonstrated a significantly reduced expression of the Maoa, 5ht1a, Sert, and lesser reduction-Tph2 mRNA levels in the mice winning 21 successive encounters each. It is noteworthy that earlier a decrease in the activity of rate-limiting enzyme in the biosynthesis of 5-HT, tryptophan hydroxylase, in the midbrain was shown for the winners $[16,17]$. Thus, a chronic manifestation of aggression, which, as supposed earlier, is accompanied by the inhibition of the brain serotonergic system [15], decreases the expression of the serotonergic genes, whose products are responsible for the inactivation and reception of 5-HT. After no-fight period expression of the Tph2 and Sert genes increases significantly versus the period before deprivation and to a larger degree for the Maoa, and $5 h t 1$ a genes versus the respective controls. Overexpression of genes after deprivation may be considered as common feedback mechanism initiated by cessation of agonistic interactions. The data obtained so far strongly support the statement that the serotonergic genes are involved in the mechanisms of repeated aggression and do not contradict the serotonin deficiency hypothesis of aggression $[4,6]$, which associates the decreased 5-HT function and increased aggression. From this statement, it follows that serotonin inhibits aggression. Based on our data it is plausible to assume that the repeated experience of aggression inhibits the brain serotonergic activity and changes the 5-HT metabolism, reception and serotonergic gene expression.

It is noteworthy, that reduced mRNA levels of the genes of interest in this area have been found in the animals with repeated experience of defeats [26]. Similarity of changes in male mice with alternative social behaviors, manifested by chronic defeats or aggression casts doubt on the specificity of such changes for aggression. Earlier we assumed [44] that similar changes in the winners and losers may be explained by influence of agonistic interactions stress common for both participants of social conflicts or by development of enhanced level of anxiety shown both in the winners [24] and losers [45]. However we should also take into consideration the different dynamics of gene expression changes during period without agonistic interactions. In the losers period of 2 weeks of relative rest is not enough to recover expression of all serotonergic genes as well as the Creb gene to the control levels [26]. In the winners during no-fight period most genes fully restore their expression. The Maoa and Htrla genes are expressed at significantly higher levels. Thus, different mechanisms of brain serotonergic hypofunction can be assumed in the mice with alternative social behaviors. In the losers, strong decrease of serotonergic activity may be attributed to the development of a depressionlike condition with the symptoms, sensitivity to antidepressants and neurochemical changes similar to those in depressive patients $[36,45,46]$. In the winners behavioral 
psychopathology developing under positive fighting experience [15] is associated with inhibition of brain serotonergic system. Recovering of the Tph2 and Sert gene expression and overexpression of Maoa and Htrla genes after no-fight period in the winners suggests that changes in brain serotonergic activity are not the main or only cause of the behavioral pathology developing in male mice in this experimental context. Obviously, other neurotransmitter systems may also be the factors, for example, the brain dopaminergic systems, which have been found to alter in the 21-time winners. Activation of the brain dopaminergic systems has been demonstrated in male mice with prolonged positive fighting experience as elevated DOPAC (3,4-dihydroxyphenyleacetic acid) levels or/and increased DOPAC/DA (dopamine) ratios in different brain areas [15]. The DA level was increased in the prefrontal cortex during and after fights in aggressive rats [8]. Upregulation of the Th, and Dat 1 gene expression has also been found in the ventral tegmental area of the winners $[23,47]$. In the fighting deprived winners these genes retained increased expression as compared with the controls. Interestingly, in the losers' ventral tegmental area lack of significant changes in the Th and Dat1 gene expression was found [23]. Activation of the Th and Comt gene expression was also found in the cerebellum, frontal cortex, hippocampus, midbrain, and striatum [48]. Thus, all data support the idea that repeated experience of aggression results in disbalance between activities of two neurotransmitter systems-serotonergic and dopaminergic [15], namely the inhibition of the former and activation of the latter, which are part of the catecholamine systems responsible for several functions, including excitation of nervous processes. In such circumstances a low threshold for aggressive behavior has been established, and, therefore, aggression can be demonstrated even in low provocative conditions. There is a lot of experimental evidences for the relationship between increased impulsivity and, as a consequence, increased aggression, and reduced serotonergic activity in humans and animals $[9-11,49]$. The results of our studies are consistent with these data.

As mentioned above, chronic positive fighting experience is accompanied by development of behavioral pathology symptoms [15,49] in male mice such as abnormal aggression, hostility, pronounced anxiety, disturbances in social recognition and motivated behavior, hyperactivity, stereotypic and hyperkinetic reactions etc. After fighting deprivation the male mice have been shown to demonstrate higher aggressiveness as compared with a period before deprivation [20,21]. Therefore, it can be assumed that serotonergic system is not responsible for this phenomenon since serotonergic genes recover their expression after cessation of agonistic interactions. The brain dopaminergic and opioidergic systems retain their changed functional activity $[15,47]$ and may be suspected as being the key factors of increased aggression after no-fight periods.

\section{ACKNOWLEDGEMENTS}

This work was supported partly by Research Program from the Russian Academy of Sciences "Molecular and Cellular Biology”, grant no 6.25, and Russian Foundation for Basic Research, grant no 13-04-00072a.

\section{REFERENCES}

[1] Poshivalov, V.P. (1986) Experimental psychopharmacology of aggressive behavior. Nauka, Leningrad, 175.

[2] Vergnes, M., Depaulis, A. and Boehrer, A. (1986) Parachlorophenylalanine induced serotonin depletion increases offensive but not defensive aggression in male rats. Physiology and Behavior, 36, 653-658. http://dx.doi.org/10.1016/0031-9384(86)90349-5

[3] Miczek, K.A. and Donat, P. (1989) Brain 5-HT system and inhibition of aggression. In: Bevan, P., Cools, A.R. and Archer, T., Eds., Behavioural Pharmacology of 5-HT. LEA Publishers, Augusta, 117-144.

[4] de Boer, S.F. and Koolhaas, J.M. (2005) 5-HT1A and 5-HT1B receptor agonists and aggression: A pharmacological challenge of the serotonin deficiency hypothesis. European Journal of Pharmacology, 526, 125-139. http://dx.doi.org/10.1016/j.ejphar.2005.09.065

[5] Olivier, B. and Mos, J. (1992) Rodent models of aggressive behavior and serotonergic drugs. Progress in NeuroPsychopharmacology and Biological Psychiatry, 6, 847870. http://dx.doi.org/10.1016/0278-5846(92)90104-M

[6] Miczek, K.A., Faccidomo, S.P., Fish, E.W. and DeBold, J.F. (2007) Neurochemistry and molecular neurobiology of aggressive behavior. In: Lajtha, A. and Blaustein, J.D., Eds., Handbook of Neurochemistry and Molecular Neurobiology: Behavioral Neurochemistry, Neuroendocrinology and Molecular Neurobiology, Springer-Verlag, Berlin/Heidelberg, 285-336. http://dx.doi.org/10.1007/978-0-387-30405-2_ 7

[7] Popova, N.K. (2008) From genes to aggressive behavior: The role of serotonergic system. Bioessays, 5, 495-503.

[8] Van Erp, A.M. and Miczek, K.A. (2000) Aggressive behavior, increased accumbal dopamine, and decreased cortical serotonin in rats. Journal of Neuroscience, 20, 93209325.

[9] Brown, G.L., Ebert, M.H., Goyer, P.F., Jimerson, D.C., Klein, W.J., Bunney, W.E. and Goodwin, F.K. (1982) Aggression, suicide, and serotonin: Relationships to CSF metabolites. American Journal of Psychiatry, 139, 741-746.

[10] Linnoila, M., Virkkunen M., Scheinin M, Nuutila A., Rimon R. and Goodwinn, F.K. (1983) Low cerebrospinal fluid 5-hydroxyindoleacetic acid concentration differentiates impulsive from nonimpulsive violent behavior. Life Science, 33, 2609-2614. http://dx.doi.org/10.1016/0024-3205(83)90344-2

[11] Lidberg, L., Asberg, M. and Sundqvist-Stenman, U.B. 
(1984) 5-hydroxyindoleacetic acid levels in attempted suicides who have killed their children. Lancet, 2, 928. http://dx.doi.org/10.1016/S0140-6736(84)90683-4

[12] Coccaro, E.F. (1992) Impulsive aggression and central serotonergic system function in humans: An example of a dementional brain behavior relationship. International Clinical Psychopharmacology, 7, 3-12. http://dx.doi.org/10.1097/00004850-199200710-00001

[13] Cherek, D.R., Moeller, F.G., Khan-Dawood, F., Swann, A. and Lane, S.D. (1999) Prolactin response to buspirone was reduced in violent compared to nonviolent parolees. Psychopharmacology, 142, 144-148. http://dx.doi.org/10.1007/s002130050873

[14] Kudriavtseva, N.N. and Bakshtanovskaia, I.V. (1991) The neurochemical control of aggression and submission. I.P. Pavlov Journal of Higher Nervous Activity, 41, 459-466.

[15] Kudryavtseva, N.N. (2006) Psychopathology of repeated aggression: A neurobiological aspect. In: Morgan, J.P. Ed., Perspectives on the Psychology of Aggression, NOVA Science Publishers, Inc., 35-64.

[16] Kulikov, A.V., Kozlachkova, E.Y., Kudryavtseva, N.N. and Popova, N.K. (1995) Correlation between tryptophan hydroxylase activity in the brain and predisposition to pinch-induced catalepsy in mice. Pharmacology, Biochemistry, and Behavior, 50, 431-435. http://dx.doi.org/10.1016/0091-3057(94)00293-R

[17] Amstislavskaya, T.G. and Kudryavtseva, N.N. (1997) Effect of repeated experience of victory and defeat in daily agonistic confrontations on brain tryptophan hydroxylase activity. FEBS Letters, 406, 106-108. http://dx.doi.org/10.1016/S0014-5793(97)00252-4

[18] Bondar, N.P. and Kudriavtseva, N.N. (2003) Effect of buspirone on aggressive and anxiety behavior of male mice with various aggressive experience. Experimental and Clinical Pharmacology, 66, 12-16.

[19] Avgustinovich, D.F., Alekseyenko, O.V. and Tenditnik, M.V. (2001) Fighting among C57BL/6J mice and its implications for $[3 \mathrm{H}] 8$-hydroxy-N, N-dipropyl-2-aminotetralin binding in various brain regions. Neuroscience Letters, 305, 189-192. http://dx.doi.org/10.1016/S0304-3940(01)01850-X

[20] Smagin, D.A., Bondar, N.P. and Kudryavtseva, N.N. (2010) Repeated aggression and implications of deprivation in male mice. Psychopharmacology and Biological Narcology, 10, 2636-2648.

[21] Kudryavtseva, N.N., Smagin, D.A. and Bondar, N.P. (2011) Modeling fighting deprivation effect in mouse repeated aggression paradigm. Progress in Neuro-Psychopharmacology and Biological Psychiatry, 35, 1472-1478. http://dx.doi.org/10.1016/j.pnpbp.2010.10.013

[22] Kudryavtseva, N.N. (1991) The sensory contact model for the study of aggressive and submissive behaviors in male mice. Aggressive Behavior, 17, 285-291. http://dx.doi.org/10.1002/1098-2337(1991)17:5<285::AI D-AB2480170505>3.0.CO;2-P

[23] Filipenko, M.L., Alekseyenko, O.V., Beilina, A.G., Kamynina, T.P. and Kudryavtseva, N.N. (2001) Increase of tyrosine hydroxylase and dopamine transporter mRNA levels in ventral tegmental area of male mice under influence of repeated aggression experience. Brain Research, Molecular Brain Research, 96, 77-81.

http://dx.doi.org/10.1016/S0169-328X(01)00270-4

[24] Kudryavtseva, N.N., Bondar, N.P. and Avgustinovich, D.F. (2002) Association between experience of aggression and anxiety in male mice. Behavioral Brain Research, $\mathbf{1 3 3}$ 83-93. http://dx.doi.org/10.1016/S0166-4328(01)00443-0

[25] Rosen, G.D., Williams, A.G., Capra, J.A., Connolly, M.T., Cruz, B., et al. (2000) The Mouse Brain Library@ www.mbl.org. Int Mouse Genome Conference, 14, 166. www.mbl.org

[26] Boyarskikh, U.A., Bondar, N.P., Filipenko, M.L. and Kudryavtseva, N.N. (2013) Downregulation of serotonergic genes expression in the raphe nuclei of midbrain under chronic social defeat stress in male mice. Molecular Neurobiology, 48, 3-21. http://dx.doi.org/10.1007/s12035-013-8413-y

[27] Cook, N.L., Vink, R., Donkin, J.J. and van den Heuvel, C. (2009) Validation of reference genes for normalization of real-time quantitative RT-PCR data in traumatic brain injury. Journal of Neuroscience Research, 87, 34-41. http://dx.doi.org/10.1002/jnr.21846

[28] Valente, V., Teixeira, S.A., Neder, L., Okamoto, O.K., ObaShinjo, S.M., et al. (2009) Selection of suitable housekeeping genes for expression analysis in glioblastoma using quantitative RT-PCR. BMC Molecular Biology, 10, 17. http://dx.doi.org/10.1186/1471-2199-10-17

[29] Passmore, M., Nataatmadja, M. and Fraser, J.F. (2009) Selection of reference genes for normalisation of realtime RT-PCR in brain-stem death injury in Ovis aries. BMC Molecular Biology, 10, 72. http://dx.doi.org/10.1186/1471-2199-10-72

[30] Chari, R., Lonergan K.M., Pikor, L.A., Coe, B.P., Zhu, C.Q., et al. (2010) A sequence-based approach to identify reference genes for gene expression analysis. $B M C M e-$ dical Genomics, 3, 32.

http://dx.doi.org/10.1186/1755-8794-3-32

[31] Otis, J.P., Ackermann, L.W., Denning, G.M. and Carey, H.V. (2010) Identification of qRT-PCR reference genes for analysis of opioid gene expression in a hibernator Journal of Comparative Physiology B, 180, 619-629. http://dx.doi.org/10.1007/s00360-009-0430-9

[32] Wierschke, S., Gigout, S., Horn, P., Lehmann, T.N, Dehnicke, C., et al. (2010) Evaluating reference genes to normalize gene expression in human epileptogenic brain tissues. Biochemical and Biophysical Research Communication, 403, 385-390. http://dx.doi.org/10.1016/j.bbrc.2010.10.138

[33] Numakawa, T., Suzuki, S., Kumamaru, E., Adachi, N., Richards, M., et al. (2010) BDNF function and intracellular signaling in neurons. Histology and Histopathology, 25 237-258.

[34] Pizarro, J.M., Lumley, L.A., Medina, W., Robison, C.L., Chang, W.E., et al. (2004) Acute social defeat reduces neurotrophin expression in brain cortical and subcortical areas in mice. Brain Research, 1025, 10-20. http://dx.doi.org/10.1016/j.brainres.2004.06.085

[35] Abumaria, N., Rygula, R., Havemann-Reinecke, U., Ruther, E., Bodemer, W., et al. (2006) Identification of genes 
regulated by chronic social stress in the rat dorsal raphe nucleus. Cellular and Molecular Neurobiology, 26, 145162. http://dx.doi.org/10.1007/s10571-006-9024-1

[36] Berton, O., McClung, C.A., Dileone, R.J., Krishnan, V., Renthal, W., et al. (2006) Essential role of BDNF in the mesolimbic dopamine pathway in social defeat stress. Science, 311, 864-868. http://dx.doi.org/10.1126/science.1120972

[37] Boer, U., Alejel, T., Beimesche, S., Cierny, I., Krause, D., et al. (2007) CRE/CREB-driven up-regulation of gene expression by chronic social stress in CRE-luciferase transgenic mice: Reversal by antidepressant treatment. PLoS One, 2, e431. http://dx.doi.org/10.1371/journal.pone.0000431

[38] Gomez-Lazaro, E., Arregi, A., Beitia, G., Vegas, O., Azpiroz, A., et al. (2011) Individual differences in chronically defeated male mice: Behavioral, endocrine, immune, and neurotrophic changes as markers of vulnerability to the effects of stress. Stress, 14, 537-548. http://dx.doi.org/10.3109/10253890.2011.562939

[39] Ito, W., Chehab, M., Thakur, S., Li, J. and Morozov, A. (2011) BDNF-restricted knockout mice as an animal model for aggression. Genes, Brain and Behavior, 3, 365374. http://dx.doi.org/10.1111/j.1601-183X.2010.00676.x

[40] Sotiropoulou, M., Mantas, C., Bozidis, P., Marselos, M., Mavreas, V., Hyphantis, T. and Antoniou, K. (2013) BDNF serum concentrations in first psychotic episode drug-naïve schizophrenic patients: Associations with personality and BDNF Val66Met polymorphism. Life Science, 92, 305-310.

[41] Taylor, S.L., Stanek, L.M., Ressler, K.J. and Huhman, K.L. (2011) Differential brain-derived neurotrophic factor expression in limbic brain regions following social defeat or territorial aggression. Behavioral Neuroscience, 125, 911-920. http://dx.doi.org/10.1037/a0026172

[42] Kudryavtseva, N.N., Bondar, N.P., Boyarskikh, U.A. and Filipenko, M.L. (2010) Snca and Bdnf gene expression in the ventral tegmental area and raphe nuclei of midbrain in chronically victorious and defeated male mice. PLoS One, 5, e14089.
[43] Martinowich, K. and Lu, B. (2008) Interaction between BDNF and serotonin: Role in mood disorders. Neuropsychopharmacology, 33, 73-83. http://dx.doi.org/10.1038/sj.npp.1301571

[44] Avgustinovich, D.F., Gorbach, O.V. and Kudryavtseva, N.N. (1997) Comparative analysis of anxiety-like behavior in partition and plus-maze tests after agonistic interactions in mice. Physiology and Behavior, 61, 37-43. http://dx.doi.org/10.1016/S0031-9384(96)00303-4

[45] Kudryavtseva, N.N. and Avgustinovich, D.F. (1998) Behavioral and physiological markers of experimental depression induced by social conflicts (DISC). Aggressive Behavior, 24, 271-286.

http://dx.doi.org/10.1002/(SICI)1098-2337(1998)24:4<27 1::AID-AB3>3.0.CO;2-M

[46] Avgustinovich, D.F., Alekseyenko, O.V., Bakshtanovskaya, I.V., Koryakina, L.A., Lipina, T.V., Tenditnik, M.V., Bondar, N.P., Kovalenko, I.L. and Kudryavtseva, N.N. (2004) Dynamic changes of brain serotonergic and dopaminergic activities during development of anxious depression: Experimental study. Advances in Physiological Science, 35, 19-40.

[47] Bondar, N.P., Boyarskikh, U.A., Kovalenko, I.L., Filipenko, M.L. and Kudryavtseva, N.N. (2009) Molecular implications of repeated aggression: Th, Dat1, Snca and Bdnf gene expression in the ventral tegmental area of victorious male mice. PLoS One, 4, e4190. http://dx.doi.org/10.1371/journal.pone.0004190

[48] Ginsberg, S.D., Che, S., Hashim, A., Zavadil, J., Cancro, R., Lee, S.H., Petkova, E., Sershen, H.W. and Volavka, J. (2011) Differential regulation of catechol-O-methyltransferase expression in a mouse model of aggression. Brain Structure and Function, 216, 347-356. http://dx.doi.org/10.1007/s00429-011-0315-Z

[49] Caramaschi, D., de Boer, S.F., de Vries, H. and Koolhaas, J.M. (2008) Development of violence in mice through repeated victory along with changes in prefrontal cortex neurochemistry. Behavioral Brain Research, 189, 263272. http://dx.doi.org/10.1016/j.bbr.2008.01.003 